January 2019

\title{
Preparing School Counselors in training to implement English as a Second Language (ESL) strategies during classroom lessons
}

Leonissa Johnson

Clark Atlanta University, ljohnson@cau.edu

Amy Cain

Cobb County Schools, dcaina@aol.com

Follow this and additional works at: https://digitalcommons.georgiasouthern.edu/ij-sotl

\section{Recommended Citation}

Johnson, Leonissa and Cain, Amy (2019) "Preparing School Counselors in training to implement English as a Second Language (ESL) strategies during classroom lessons," International Journal for the Scholarship of Teaching and Learning: Vol. 13: No. 1, Article 9.

Available at: https://doi.org/10.20429/ijsotl.2019.130109 


\title{
Preparing School Counselors in training to implement English as a Second Language (ESL) strategies during classroom lessons
}

\begin{abstract}
School counselors provide academic, social-emotional, and college and career access information to all students via core curriculum classroom lessons. English Learners benefit from differentiated classroom instruction that makes content engaging and accessible. Despite this need for differentiated instruction, few educators have received English as a Second Language (ESL) teaching strategies training. This mixed methods study examined how an ESL teaching strategies workshop influenced the utilization of these approaches by school counselors in training. A triangulation mixed methods design was used to collect complementary data about participant behavior and thinking. Modeling ESL strategies alone did not yield statistically significant differences in the types of strategies implemented by school counselors in training. However, participants did become more aware of the needs of English Learners and actions that could promote classroom engagement. Implications for training, research, and the scholarship of teaching and learning are discussed.
\end{abstract}

\section{Keywords}

English Learners, School Counselors in training, Differentiated instruction, Core Curriculum lessons, Engagement

\section{Creative Commons License} c) (i) $९$

This work is licensed under a Creative Commons Attribution-Noncommercial-No Derivative Works 4.0 License. 
IJ-SoTL, Vol. 13 [2019], No. 1, Art. 9

\title{
Preparing School Counselors in Training to Implement English as a Second Language (ESL) Strategies during Classroom Lessons
}

\author{
Leonissa Johnson' and Amy Cain² \\ I Clark Atlanta University \\ 2 Cobb County Schools
}

Received: October 4, 2017;Accepted October 9, 2018

\begin{abstract}
School counselors provide academic, social-emotional, and college and career access information to all students via core curriculum classroom lessons. English Learners benefit from differentiated classroom instruction that makes content engaging and accessible. Despite this need for differentiated instruction, few educators have received English as a Second Language (ESL) teaching strategies training. This mixed methods study examined how an ESL teaching strategies workshop influenced the utilization of these approaches by school counselors in training. A triangulation mixed methods design was used to collect complementary data about participant behavior and thinking. Modeling ESL strategies alone did not yield statistically significant differences in the types of strategies implemented by school counselors in training. However, participants did become more aware of the needs of English Learners and actions that could promote classroom engagement. Implications for training, research, and the scholarship of teaching and learning are discussed.
\end{abstract}

When the first author consistently saw school counselors in training read slides word-for-word, stand in one location, and only call on volunteers during mock classroom guidance lessons, she felt compelled to respond to these observations. She wondered what would help students develop more engaging presentations. She and the second author, an English as a second language (ESL) teacher, wondered whether providing opportunities for school counselors in training to observe strategies would result in their implementation of those strategies.

Professors of students in any education-related field hope that student knowledge of strategies extends beyond awareness of information to implementation of those strategies during presentations and other classroom situations. The researchers concluded that a first step in this specific situation would be to introduce school counselors in training to ESL strategies with the hope that observing and experiencing the strategies would result in implementation of them. For this reason, they designed and implemented the study described in this article.

The Association of American Colleges and Universities [AAC\&U] (2009) recognized effective oral communication as an essential learning outcome across disciplines in higher education. Faculty members consider language use, eye contact, and relevant supporting materials when evaluating student presentations (AAC\&U, 2009). Students in education-related fields must not only communicate in compelling ways, but also make their messages comprehensible to diverse learners. Scholarship of Teaching and Learning (SoTL) "involves studying, reflecting on, and communicating about teaching and learning (Healy, 2003, p. 14). In the spirit of SoTL, this article examines the impact of an ESL teaching strategies workshop on presentation skills.

\section{School counselors, English Learners, and comprehensible content}

School counselors' raison d'être is to provide access and equitably serve all students to help them reach their academic, career and social-emotional goals (American School Counselor Association [ASCA], 20I2; Portman, 2009). English Learners (ELs) comprise approximately 10 percent of the kindergarten through I 2 th grade school population in the United States (U.S. Department of Education [DOE], 2017). These changing student demograph- ics create both opportunities and challenges for school counselors. English Learners have lower graduation rates, limited access to college and career readiness programs, and limited placement into gifted education programs compared to their White counterparts (DOE, 2017). School counselors share academic, college, and career success information via core curriculum lessons (ASCA, 20I2). With an increasing number of English Learners in public schools, school counselors must find approaches to core curriculum instruction that allow English Learners to understand and utilize the information.

In states across the country the number of students served in English as a Second Language (ESOL) programs is increasing (DOE, 2017). The Georgia metropolitan area where this study was conducted has approximately 580,000 Latinos-more than Corpus Christi, Tampa, Fort Lauderdale, or Tucson (Pew Hispanic Research Center, 2017). Particularly following the New Latino Diaspora (Hamann, Wortham, \& Murillo, 2002; Murillo, 2002; and Villenas, 2002) schools in the Southeastern United States have more Spanish-speaking students (Pew Hispanic Research Center, 2015). However, most educators have not received specialized training or professional development relating to these students (Ballantyne, Sanderman, \& Levy, 2008; Barrera \& Jiménez, 2000; Carrasquillo \& Rodríguez, 2002; Dove \& Honigsfeld, 2010; Echevarria, Short, \& Powers, 2006; Kim, 20I0; Walker, Shafer, \& liams, 2004).

Echevarria, Short, and Powers (2006) emphasized making content comprehensible. The World-class Instructional Design and Assessment organization [WIDA] (20I2) delineates the importance of receptive (listening and reading) and productive (speaking and writing) communication for second language learners. In efforts to provide specialized training about English Learners, and to examine choices that school counselors in training make when planning and delivering content, the researchers planned and implemented this study. The researchers focused on making school counselors in training aware of strategies that support English Learners' comprehension and participation in core curriculum lessons.

This mixed methods study examined how a workshop that introduced English as a Second Language (ESL) teaching strategies informed the utilization of those strategies by school coun- 
selors in training. Mixed methods approaches are used in SoTL research to provide a more "complete picture" of an educational phenomenon (Bishop-Clark \& Dietz-Uhler, 20I2, p. 59). A triangulation mixed methods design was used to collect complementary data about participant behavior and thinking. In this study, the ESL Teaching Strategies Rubric was used to compile the ESL teaching strategies used by the participants during two presentations. In addition to analyzing the quantitative data, the two researchers prepared and analyzed Presentation Reflections using content analysis techniques to explore participant thinking about engagement and planning choices. The collection of both quantitative and qualitative data allowed the researchers to explore participants' presentation choices more fully.

The main research question directing this study was: How does an ESL teaching strategies workshop influence school counselor in training presentation behavior and thought? Several sub-questions - quantitative and qualitative-guided the study. The quantitative sub-questions were: (I) What ESL strategies do school counselors in training implement in their presentations? and (2) Is there a significant difference in the use of ESL teaching strategies by school counselors in training after an ESL teaching strategies workshop? The qualitative sub-questions were: (I) How did the ESL strategies workshop influence or inform participants' understanding of engagement? (2) How did the ESL strategies workshop influence or inform students' understanding of the needs of English Learners?

Because both researchers had presented lessons in elementary school classes that included English Learners, had completed ESOL endorsement requirements, and had lived or studied abroad, they were aware of training needs for school counselors in training. The desire to conduct this study grew out of the researchers' personal experiences as educators, learners, and international travelers. The researchers also were inspired by the need for educators to better understand and meet the needs of English Learners (Matthews, 2007). Additionally, the authors aimed to help students incorporate engaging strategies into their presentations and/or teaching. The explication of those needs is detailed in the review of the literature.

\section{LITERATURE REVIEW}

Traditionally, a literature review may fulfill several purposes. Webster and Watson (2002) state that the purpose or intent of a literature review is to establish a foundation for advancing knowledge, facilitate the development of theory, and reveal areas where gaps in research exist and where additional research is needed. In this article, the literature review will include three parts: the literature that informed the planning and implementation of the study, the theoretical framework undergirding and guiding the study, and the literature that shed light on the findings and discussion. The following section begins with the literature that inspired the planning and implementation of the study.

\section{Literature that Influenced the Planning and Implementation of the Study}

School counselors are charged with helping all students succeed in school through academic and social-emotional supports.Additionally, school counselors assist students and families with college and career preparation and planning (ASCA, 20I2; Portman, 2009). The American School Counselors Association (ASCA) developed a model to help counselors develop and deliver eq- uitable and comprehensive counseling services to all students (ASCA, 20I2). One component of the ASCA Model is core curriculum lessons. While core curriculum lessons are a significant element of school counseling delivery, training and research in this area have been scarce.

Core curriculum lessons. School counseling core curriculum, formerly called classroom guidance, "consists of a planned, written instructional program that is comprehensive in scope, preventive in nature and developmental in design" (ASCA, 20I2, p. 28). The core curriculum is provided systematically to all students via instruction or group activities (ASCA, 20I2). School counseling core curriculum can comprise 25 to 45 percent of school counselor time and delivers academic, career, and social-emotional knowledge, attitudes, skills, and resources to all students (ASCA, 20I2). Counselor preparation standards require that school counselors in training learn differentiated strategies for instruction during those lessons (Council for Accreditation of Counseling \& Related Educational Programs, 2016). Akos Cockman, and Strickland (2007) explained the importance of differentiating core curriculum based on student readiness, interests, and learning profiles. Akos, et al. (2007) also noted the limited research exploring the training of school counselors to deliver classroom lessons effectively. Further, while school counselors are required to meet the needs of English Learners, some have reported feeling ill-equipped and having limited resources to serve these students effectively (Clemente \& Collison, 2000; Schwallie-Giddis, Anstrom, Sanchez, Sardi, \& Granato, 2004; Villalba, Lewis, \&Watcher, 2007). Other school counselors have implemented academic and personal social interventions such as small groups or individual counseling (Cook, Pérusse, \& Rojas, 2012), but few studies have examined differentiation in core curriculum for English Learners.

English Learners. Schools are responding to English Learners in a variety of ways. Although the federal government requires that all students legally and morally deserve an appropriate education and educators must provide adequate instruction for ELs (Lau versus Nichols), some educators provide inappropriate or no modification of instruction, assessment, and activities (Matthews, 2007). Teachers and counselors may assume that ELs are someone else's "problem" (Lee \& Oxelson, 2006; Matthews, 2007). Approaches may marginalize students (Matthews, 2007). English Learners benefit from a school climate that values bilingualism; however, many educators rarely acknowledge children's first language (LI) (Matthews, 2007).

Although state programs to address the needs of English Learners began in the 1970s (Fitzgerald, 1993), the number and diversity of ELs today necessitates more intervention or attention to the issue. "English-dominant mainstream teachers' understanding of second language acquisition processes and their attitudes toward native language use can play a crucial role in the educational experiences and outcomes of ELL students" (Karathanos, 2009, p. 620).

Meyer (2000) challenged educators to become aware of and to strive to remove barriers to meaningful instruction for English Learners. These barriers include: cognitive load, culture load, language load, and learning load. Culture load includes ways educators expect talk to happen in classrooms. "Teachers may have strong beliefs about when students should speak in class and when they should not" (p. 23I). These beliefs differ from country to country, from region to region, and from one educator to an- 
other. When school counselors spark students' curiosity and interest in learning, Meyer contends that a "yearning" is unleashed that will inspire students to overcome these barriers (p. 229). She encourages educators to become aware of students' funds of knowledge (González, Moll, \& Amanti, 2005) and to communicate conceptual connections to build on students' prior experiences and background knowledge.

\section{Theoretical Framework}

The theoretical framework for the study included sociocultural theory and critical theory. Vygotsky $(1978,1986)$ affirmed the importance of relationships and articulated the social context for learning. The study is especially influenced by Vygotsky's constructs of Zone of Proximal Development (ZPD) and More Knowledgeable Other (MKO) (Vygotsky, 1978, 1986). Freire (1970) espoused dialogic teaching - not merely the transmission of content, but interactions between and among learners. The workshop that was planned to introduce school counselors in training to ESL strategies implemented ZPD and dialogic, participatory teaching and learning.

\section{Literature that Informed Findings and Discussion}

The researchers alternated between the data and the literature during the data analysis to make sense of the findings and to consider possible explanations for participants' behavior. Glaser and Strauss (1967) advise not doing the literature review before conducting the study to avoid influencing analysis of the data. This premise supports the researchers' continuing to explore the literature throughout data analysis and articulation of findings and discussion.

During the content analysis and during discussions, the researchers explored several theories while attempting to make sense of the findings and to consider possible explanations for what was observed in participants' behavior. These theories include social learning theory (Bandura, 1977), particularly the "Observational Learning Model," and expertise (Tsui, 2003). The following section addresses each of those theories in more detail.

Social learning theory. Bandura (1977) developed social learning theory, later referred to as social cognitive theory (Bandura, 1977, 1986). Bandura's theory identified the processes that occur during observational learning: attention, retention, production, and motivation (Miller, 2002). Individuals may learn from live models; persons engaging in specific behaviors, verbal models; descriptions of specific behaviors, or symbolic models; real or fictional models demonstrating behaviors through media sources (Bandura, 1977; Lim, 20I5).

Initially, individuals must attend to the significant aspects of a behavior before it can have influence (Bandura, 1986). A model can command the attention of an individual through different means such as attractiveness, status, or power (Miller, 2002). Modeled behavior will not stay with an individual unless it is retained. Bandura (1986) described retention as symbolic representation which requires the brain to translate behavior into symbols and integrate the information. Further, individuals must cognitively rehearse, or see themselves successfully engaging in a behavior with the anticipated outcomes. A person also must have enactive rehearsal or verbal rehearsal of the behavior (Bandura, 1986; Miller, 2002). During production processes, individuals transform observations into action (Bandura, 1986). Learners perform the behaviors and receive feedback from models or culture. Individuals may modify behavior based on this feedback (Miller, 2002). Finally, individuals reproduce behaviors that have external, vicarious, or self-incentives. (Miller, 2002). Individuals continue engaging in behaviors that they are motivated to reproduce (Bandura, 1986). In addition to exploring Bandura's social learning theory, the researchers also investigated the possible implications of educator expertise.

Expertise. The researchers considered theory relating to expertise - articulating a progression of difficulty in participants' incorporation of strategies in their presentations and reflecting on the possibility of a continuum from novice to expert. The researchers explored literature relating to expertise during the crafting of the discussion and implications sections of this article. Novice educators may have difficulty knowing what is most important in their teaching-learning interactions with students (Tsui, 2003). Reynolds (2005) wrote about teachers' not being able to perceive certain areas just as a frog cannot see flies at certain angles from the frog's eyes. Just as individuals can see a limited range of wavelengths of light and hear only certain frequencies of sound, many novice educators (although they are not a homogeneous group) focus primarily on lesson delivery with less awareness of the audience.

Berliner (1994) posited a model of teaching expertise. He wrote that experienced educators have classroom routines and can "take advantage of teachable moments" (p. 23). He added that novice educators are less flexible. Berliner also stated that experienced educators differ in the ways they think and act. He claimed that the novice is "rigid in action," the advanced beginner is "gaining insight," and the proficient educator is "intuitive" (p. 18).

While English Learners are a growing student population and core curriculum is a significant portion of a comprehensive school counseling program, school counselors have had limited preparation in both areas (Akos et al., 2007; ASCA, 2012; Matthews, 2007). This study examines the impact of an ESL teaching strategies workshop on the behavior and thinking of school counselors in training.

\section{METHOD}

A mixed methods, triangulation design was used to capture participant behavior and thoughts during this study. Specifically, a convergence model was utilized. Within the convergence triangulation model, researchers collect quantitative and qualitative data separately, about the same incident or experience, to better understand a phenomenon (Creswell \& Plano-Clark, 2007). The researchers developed a rubric to identify ESL teaching strategies used during participant presentations. Participant presentations were observed both before and after the ESL teaching strategies workshop. Written reflections about the presentation experience also were examined using content analysis techniques.

\section{Participants}

Purposeful sampling was used in this study (Hays \& Singh, 20I2). The researchers intentionally recruited participants who met predetermined criteria (Creswell \& Plano-Clark, 2007). School counselors in training at a small, private university in the southeastern United States were the targeted participants for this study. After the researchers received permission to conduct the study from the Institutional Review Board, students enrolled in 
an introductory school counseling course taught by the first author were recruited to participate. Participation requirements included (I) enrollment in the introduction to school counseling course and (2) signed and returned informed consent. Fourteen students were enrolled in the course, and ten agreed to take part in the study.

Each participant $(N=10)$ was enrolled in a Masters in School Counseling degree program. Nine of the school counselors in training identified as female and one as a male.All the participants identified as Black or African American. Thirty percent $(n=3)$ of the school counselors in training reported earning a teacher certification. One participant received prior English as a Second Language (ESL) training. Ten percent of participants $(n=$ I) worked as teachers in schools at the time of the study. Thirty percent $(n=3)$ worked in school settings in education-related roles and 70 percent $(n=7)$ were completing school counseling practicum or internship requirements in local schools.

\section{Procedures}

During the first day of class, course participants were informed about the study and received an informed consent form. Participants had a week to review and sign the form if they agreed to take part in the study. Return of the form indicated consent.

During the third week of the semester, each participant developed and presented to the class a seven-minute presentation about a school counseling related topic. Students were instructed to develop an engaging presentation with a linguistically diverse audience in mind. Two independent observers who were trained in ESL teaching strategies scored each presentation using the ESL Teaching Strategies Rubric. Presenters were numbered for confidentiality purposes.

During the sixth week of the semester, all participants attended an ESL teaching strategies workshop facilitated by both authors. Throughout the workshop, the academic needs of English Learners were explained. Participants also practiced using specific instructional strategies for English Learners such as Total Physical Response, realia, and visuals.

Each participant prepared and delivered another seven-minute presentation about a different counseling related topic during the twelfth week of the semester. Once again, students were instructed to develop an engaging presentation with a linguistically diverse audience in mind. The same two independent observers who were trained in ESL teaching strategies scored each of the presentations using the ESL Teaching Strategies Rubric. Early-semester and later-semester presentation observation scores were analyzed using descriptive statistics and $t$-test procedures.

On the final day of the school counseling course, each participant completed a Presentation Reflection. Participants shared their thoughts and beliefs about their presentations and their preparation for the presentations over the course of the semester. The two researchers engaged in content analysis to identify themes from the participant reflections.

\section{Instruments}

The ESL Teaching Strategies Rubric was created by the authors to help observers identify ESL strategies demonstrated by participants during the early and later semester presentations. Before developing the instrument, the authors examined the literature and discussed the needs of English Learners during a lesson. Specifically, the opportunities for language production and partici- pation were pinpointed as needs of English Learner engagement during lessons (Herrell \& Jordan, 20I5;WIDA, 20I2). Lowering students' affective filter also was important (Cummins, 2000). The researchers identified seven ESL strategies that enabled English Learners to participate and understand information presented during lessons.

The ESL Teaching Strategies Rubric included the following sections: Total Physical Response, Graphic Organizers, Flexible Grouping, Visuals, Realia, Role Play, and Level Questioning. Each area included a description of the strategy and a scoring guide. Observers tallied any ESL strategies viewed during each presentation. The final section of the rubric allowed observers to provide a total number of teaching strategies observed along with additional comments about the presentations. A sample of the rubric is included in Appendix $A$.

The Presentation Reflection was developed by the researchers to capture the participants' thinking and beliefs about the presentations and the choices made during the process. The researchers examined observation data and the literature to generate questions about student thoughts and beliefs. The reflection questions were reviewed and piloted with a colleague. A sample of the reflection questions is included in Appendix B.

\section{Data Analysis Procedures}

As a part of the triangulation design, the researchers engaged in both quantitative and qualitative data analysis.

Quantitative procedure. Observational data were collected and reviewed by the independent observers using the ESL Teaching Strategies Rubric. The independent observers, a retired educator and the second author, noted any ESL teaching strategies observed during the early semester presentation. When presentations concluded, the independent observers debriefed and compared data. After the late semester presentations, the independent observers once again scored and debriefed. The early and late semester observation rubric scores were matched and placed into an Excel spreadsheet.A dependent samples $t$-test was conducted using Excel's Data Analysis Tool Pak to examine differences in scores before and after the teaching strategies workshop (Salkind, 20 I0). A frequency distribution also was conducted to determine how often specific teaching strategies were used by the participants (Salkind, 2010).

Qualitative procedure. Participants completed the Presentation Reflection, responding to five questions relating to their beliefs about engaging presentations and the strategies included in their presentations. The researchers conducted content analysis procedures informed by the Insch, Moore, and Murphy (1997) and Taylor-Powell and Renner (2003) approaches. Each researcher reviewed the reflection responses of one participant and developed codes for each response. The researchers then reviewed the codes each researcher applied and identified five tentative categories as the sample coding scheme: Purpose, Engaging means, Engaging Actions, Influences, and ESL needs. The researchers coded subsequent participant responses following this procedure and kept in mind tentative categories. After coding all participant responses, the researchers identified two additional categories-Assignment and Resource. Researchers placed codes, categories, and questions into an Excel spreadsheet. To continue purifying the coding scheme, researchers analyzed vertically responses to each question. This step contributed to construct validity because researchers determined whether the cat- 
egories were representative of or consistent with the underlying codes generated from examining each participant's responses. For reliability, the definition of each category was developed as researchers conducted initial coding of participant responses and subsequent analysis of each individual question. Researchers further analyzed data for themes, patterns, and connections within and between categories. Three of the seven categories were merged and resulted in the following four categories: (I) Meanings of engagement; (2) Actions that promoted engagement; (3) Factors influencing presentations; and (4) English Learner needs.

\section{Trustworthiness}

The researchers established trustworthiness by using several strategies. Triangulation involves utilizing multiple strategies such as observations and interviews to support findings. Forms of triangulation were used to examine participant behavior and thoughts. The authors triangulated data collection methods by utilizing participant observations and reflections to investigate engagement strategy use and understanding. Triangulation of investigators (Hays \& Singh, 20I2) or an evolving research team (Mays \& Pope, 2000) also was used during data collection. To limit bias, the second author and an outside team member conducted participant observations. Another outside team member administered and collected the Presentation reflections to promote open participant reflection.

The researchers also engaged in triangulation of theoretical perspective through peer debriefing (Patton, 2002). Throughout data collection and analysis, the researchers discussed and considered findings with each other and with other colleagues to challenge and question findings (Patton, 2002). The researchers engaged in memoing when collecting, reviewing and analyzing the presentation reflections. Memoing allowed the researchers to capture reactions and thoughts about the data during the process (Hays \& Singh, 20I2). Finally, the researchers maintained an audit trail (Hays \& Singh, 20I2). The researchers collected documents throughout the project such as observation rubrics, project timelines, and meeting notes to capture the research process.

\section{RESULTS}

The researchers aimed to better understand how an ESL teaching strategies workshop would influence school counselor in training presentation behavior and thought. More broadly, the authors wondered how modeling presentation strategies would influence student practice. During the quantitative portion of the study the researchers examined the ESL strategies used by school counselors in training and measured any differences. During the qualitative component of the study the researchers explored how the ESL strategies workshop influenced school counselor in training understanding of engagement and English Learner needs. The findings are detailed in the sections below.

\section{Quantitative Findings}

The research question, what ESL strategies do school counselors in training implement in their presentations? was explored by conducting a frequency distribution. Frequency distributions illustrate scores that occur most often (Salkind, 2007). During the early and late semester presentations, the independent observers tallied the following ESL teaching strategies demonstrated by participants: Total Physical Response, Graphic Organizers, Flex- ible Grouping, Visuals, Realia, Role Play, and Level Questioning on the ESL Teaching Strategies Rubric. The researchers compared the scores of the independent observers, accounted for any duplications between the independent observers, and calculated a numeric total for each teaching strategy. The researchers also computed the total number of strategies demonstrated overall for both the early and late semester presentations. For example, during the early semester presentation the observers noted the use of no Graphic Organizers by participants but tallied the occurrence of 12 ESL teaching strategies overall.

The strategy used most often was visuals, $66 \%(n=18)$. Specifically, participants used real images, $41 \%(n=1 \mathrm{I})$ most often during both the early, $50 \%(n=6)$ and late, $33 \%(n=5)$ semester presentations. While the participants did not utilize all the ESL strategies, there was an increase in the number of strategies utilized after the ESL workshop. ESL strategies were observed 12 times during the early semester presentation and 15 times during the late semester presentation. Details about the ESL strategies used early, late, and overall are presented in Table I.

\begin{tabular}{|c|c|c|c|c|}
\hline Strategy & Early & Late & $\begin{array}{c}\text { Frequency } \\
\mathrm{E}+\mathrm{L}\end{array}$ & $\begin{array}{c}\text { Percentage } \\
\text { Used }\end{array}$ \\
\hline TPR & 0 & 0 & 0 & $0 \%$ \\
\hline Graphic Organizers & 0 & 2 & 2 & $7 \%$ \\
\hline Visuals: Real Images & 6 & 5 & 11 & $41 \%$ \\
\hline Visuals: B\&W Images & 0 & 0 & 0 & $0 \%$ \\
\hline Visuals: B\&W Cartoon & 0 & 1 & $\mathrm{I}$ & $4 \%$ \\
\hline Visuals: Color Cartoons & 2 & 4 & 6 & $22 \%$ \\
\hline Realia & 1 & 2 & 3 & $11 \%$ \\
\hline Role Play & 0 & 0 & 0 & $0 \%$ \\
\hline Level Questioning & 0 & 0 & 0 & $0 \%$ \\
\hline Other Strategy & 3 & 1 & 4 & $15 \%$ \\
\hline Visuals Overall & 8 & 10 & 18 & $66 \%$ \\
\hline Total Strategies Observed & 12 & 15 & 27 & $100 \%$ \\
\hline \multicolumn{5}{|c|}{$\begin{array}{l}\text { Note: } \text { Early = Early semester presentation; Late }=\text { Late semester presenta- } \\
\text { tion; Frequency } \mathrm{E}+\mathrm{L}=\text { total frequency over both presentations;TPR = Total } \\
\text { Physical Response; } \mathrm{B} \& W=\text { Black and White }\end{array}$} \\
\hline
\end{tabular}

The research question, "Is there a significant difference in the use of ESL teaching strategies by school counselors in training after an ESL teaching strategies workshop?" was examined by using a $t$-test. A dependent samples $t$-test is used to measure differences in the same group in different conditions (Salkind, 2010). A dependent samples $t$-test was conducted to compare the ESL teaching strategies utilized before and after an ESL strategies training. There was not a significant difference in strategies used before $(M=0.9, S D=0.54)$ and after the ESL strategies workshop $(M=I . I, S D=0.54) ; t(9)=-0.80, p=0.005$. These results suggest that the workshop did not affect the use of ESL teaching strategies during the late semester presentation.

\section{Qualitative Findings}

The research questions (I) How did the ESL strategies workshop influence or inform participants' understanding of engagement? (2) How did the ESL strategies workshop influence or inform students' understanding of the needs of English Learners? were explored using content analysis techniques of the Presentation Reflections. The researchers identified four themes related to those questions from the content analysis of the Presentation Reflections. The themes were: (I) Meanings of engagement; (2) 
Actions that promoted engagement; (3) Factors influencing presentations; and (4) English Learner needs. The following sections describe those findings.

Engagement. Participants articulated meanings of engagement. One component of the definition involved audience participation. Participants believed that engaging lessons or presentations allowed the members of the audience to be involved. One participant explained “.... audience participation... helps with engagement." Another participant defined engagement as "interactive activity." A second component of engagement included understanding. Several school counselors in training believed that an engaging lesson allowed lesson participants to take part so that they could make sense of the lesson. One participant explained, "Questions and answers should be included in an engaging presentation.” Another participant noted, “An engaging presentation should...allow the audience to ask questions." One participant even highlighted an example of how she checked for understanding:"I used a mini quiz to make sure everyone was actually paying attention and if they was [sic] not they learn at the end from the others who answered the quiz questions." A final component of engagement included creativity. Participants believed that an engaging lesson required unique activities to bring the lessons to life. Participants described engaging presentations as "something that captures the audience's attention." One participant shared, "Pictures, descriptions, examples, and maybe even games should be included in engaging presentations."

While participants identified the components of engagement as audience participation, understanding, and creativity, participants also described actions that promoted engagement. This theme involved specific behaviors school counselors in training implemented in order to incorporate engagement into their presentations. One participant wrote: "I presented my presentation based off of my personal experiences. Whether it was myself or someone I know. I think if you provide part of your personal experience...background to your audience, you build a greater attention span but also a warm welcoming rapport."

School counselors in training also used assessment activities and visuals to make their presentations engaging. One participant noted, "I used an opening quiz and question. I also provided a visual for the audience." Another school counselor in training shared,“... I showed the actual workbook and asked how helpful it would been [sic] if we had these resources." Additionally, a participant noted his/her engaging actions as "Powerpoint and hand raising." These themes addressed school counselor in training descriptions and behaviors related to engagement. Participants also described other factors that informed their presentations.

Factors influencing presentations. School counselors in training described experiences, ideas, and knowledge that influenced what they included in their presentations. Participants noted that two areas informed them the most-prior experiences and the content of the presentation. Prior experiences included encounters participants had as students or audience members that influenced what they chose to do during their presentations. When considering what informed the presentation, one participant shared,"Presentations that I have been to or given in the past. Also ... teachers and presenters that I believe I gained the most knowledge from." Another participant noted, "Knowledge on [sic] the audience."

The content also informed student decisions about what to include in the presentations. In some instances, participants selected topics and activities based on areas in which they had prior knowledge. One participant shared, "What influenced me was kind of my familiarity of the topic." Another participant noted, "The middle school that l'm doing my practicum is becoming an IB school so I decided to do my presentation on this topic." Other participants were influenced by the actual content or topic. One participant explained, "The resource overall was amazing so I wanted to add as much information as possible." Another participant noted, "The fact that I am close to...people... who never had any resources...to help guide them on a career path." Participants shed light on the decisions they made when preparing for and conducting their presentations. Additionally, they described the needs of English Learners.

English Learner needs. Participants expressed awareness of the ways they could meet the needs of English Learners during lessons or presentations. Participants described visual support, language support, and role play or demonstration. Most participants communicated the need for visuals such as "I could have had more pictures in my presentation" or "Better photos would have helped." A few participants expressed the need for language supports. One participant suggested the use of a graphic organizer:"Providing a guided not [sic] sheet or graphic organizer to help students follow along with the presentation." Another participant suggested, "flashing translated language." Finally, one student noted that a role play or demonstration would help meet English Learner needs explaining, "Role play would have definitely help [sic]." In summary, the qualitative findings in this study include participants' general understanding of engagement during presentations and the specific understanding of English Learners' needs.

\section{Limitations}

The results of this study are not generalizable (Salkind, 2010). While the findings are informative, a larger number of participants or replicating the study in varied settings may yield more applicable findings for school counselors in training. Additionally, several actions during the course of the study may have influenced the results. English Learners were not present during the class presentations. Their presence may have necessitated the use of more ESL strategies. Since counselors in training expressed significant interest in and asked many questions about English Learners, there were time constraints during the workshop when ESL strategies were being modeled. Initially, school counselors in training had many questions relating to English Learner awareness.

\section{DISCUSSION}

Modeling ESL strategies alone did not yield statistically significant differences in the types of strategies implemented by school counselors in training. Bandura $(1977,1986)$ explained that modeled behavior would not stay with a learner unless the behavior was retained. Retention requires rehearsal, performance, and feedback. While the researchers modeled ESL strategies and allowed limited practice during the ESL workshop, participants were unable to spend time at length practicing and engaging in the ESL teaching strategies.

Student level of expertise also may explain the lack of significant differences in ESL strategy use demonstrated by participants. When describing their choices while developing their presentations, participants noted that the content informed their 
decisions more than the audience. Novice educators may have more difficulty seeing beyond the lesson planning and content (Tsui, 2003).

While the ESL strategies workshop did not yield a significant difference in presentation behavior, participants were more aware of the needs of English Learners and actions that could promote engagement. School counselors in training did increase the number of strategies incorporated into their late semester presentations. While these findings were not statistically significant, some participants utilized real images, graphic organizers, and realia during the late semester presentations. This implementation contrasted with school counselors in training using strictly visuals as observed during the early semester presentations. Further, when prompted, participants described the needs of English Learners. While modeling alone may not yield significant changes in behavior for novice educators, modeling may help increase awareness and potentially prime school counselors in training for more in-depth training or practice to differentiate instruction for English Learners and other diverse student populations.

\section{Implications}

Although brief exposure to possibilities or limited modeling of activities alone may not be sufficient for school counselors in training to implement ESL strategies, the modeling may be necessary as a step in that direction. Additionally, students may benefit from explicit expectations regarding the use of ESL strategies during lessons. Further, opportunities for practice with feedback from instructors and interactions with actual English Learners may result in more use of varied strategies during student presentations and lessons. Other SoTL researchers may benefit from this insight as well. Brief exposure to content or modeling without explicit instruction and/or opportunities to practice may not provide students with what they need to demonstrate new skills or behavior.

Counselor education programs also should consider the span of experience or backgrounds of school counselors in training. Their level of expertise may inform how school counselors in training plan for and deliver classroom lessons. Similarly, student presentations in other academic contexts may be influenced by a student's level of expertise with the content. Findings in this study suggest that when presenting newer content, students may invest more time mastering the information and less time considering their delivery. Instructors can keep this in mind when developing presentation assignments. Students also may benefit from more in-depth study of specific presentation strategies. Seeing, practicing, and reflecting on each strategy may lead counselors in training to incorporate these strategies during their lessons. Additionally, counselor training programs should examine the content and experiences used to prepare school counselors in training to differentiate classroom lessons for diverse student populations. Counselor educators may benefit from professional development and/or collaboration with ESL educators to address the bourgeoning interests and needs of school counselors in training and English Learners.

\section{Future research}

As the researchers reflected on this experience and considered next steps, several additional ideas for research emerged. In the future, researchers may start smaller in scope and focus on modeling a few strategies in depth and/or begin with fewer students.
A longer workshop and/or a series of educational experiences that include adequate time for exploration of English Learner needs and ESL teaching strategies may be beneficial for school counselors in training. The concept of practicing a few strategies in depth or providing students more time to examine a concept may also prove beneficial in other disciplines. Additionally, studies that examine the knowledge and experiences of counselor educators and ESL strategies may be valuable.

\section{CONCLUSION}

The researchers continue to strive to serve as advocates for students in general and for English Learners in particular. This advocacy takes many forms. Some institutions hire consultants to enhance awareness of diversity. One colleague describes her work as "ESOLizing" materials for schools. School counselors have ongoing opportunities to "ESOLize" presentations and materials-making academic, career, and social-emotional content comprehensible for diverse groups of students. The researchers hoped to influence school counselors in training to strengthen relationships and become more aware of who English learners are and what they need in the classroom. While the ESOL strategies workshop did not yield significantly different strategies in school counselor in training presentations, participants were aware of English Learner needs. This study provides insights and direction for educators aiming to further "ESOLize" school culture and programs. Additionally, the study highlights the gulf between student awareness and implementation of presentation strategies. Faculty concerned with how students deliver information to audiences can consider the findings of this study. Mere exposure is not enough. Practice, feedback, and familiar content may be essential for engaging presentations.

\section{REFERENCES}

Akos, P., Cockman, C., \& Strickland, C. (2007). Differentiating classroom guidance. Professional School Counseling, 10(5), 455-463.

American School Counselor Association. (20I2). The ASCA National Model:A Framework for School Counseling Programs, Third Edition. Alexandria,VA:Author.

Association of American Colleges and Universities. (2009). Oral communication VALUE Rubric. Retrieved from www.aacu.org/ value/rubrics/oral-communication

Ballantyne, K. G., Sanderman, A. R., \& Levy, J. (2008). Educating English Language Learners: Building Teacher Capacity. Roundtable Report. National Clearinghouse for English Language Acquisition and Language Instruction Educational Programs. Downloaded from www.ncela.us/files/uploads/3/ EducatingELLsBuildingTeacherCapacityVoll.pdf

Bandura,A. (1977). Social learning theory. Englewood Cliffs, NJ: Prentice-Hall.

---. (1986). Social foundations of thought and action: A social cognitive theory. Englewood Cliffs, NJ: Prentice-Hall.

Barrera, R. B. \& Jiménez, R. T. (2000). Literacy instruction for bilingual Latino students:Teachers' experiences and knowledge. In A research symposium on high standards in reading for students from diverse language groups: Research, practice and policy. Symposium conducted at the meeting of the U.S. Department of Education, Office of Bilingual Education and Minority Languages Affairs, Washington, DC.

Berliner, D. C. (1994). A model of teaching expertise. Continuing 
discussions in teacher certification testing. Retrieved from images.pearsonassessments.com/images/NES_Publications/I994_05Berliner_339_I.pdf

Bishop-Clark, C. \& Dietz-Uhler, B. (20I2). Engaging in the scholarship of teaching and learning:A guide to the process and how to develop a project from start to finish. Sterling,VA: Stylus Publishing, LLC.

Carrasquillo,A. \& Rodríguez, V. (2002). Language minority students in the mainstream classroom, 2nd Ed. Bristol, UK: Multilingual Matters, Ltd.

Clemente, R., \& Collison, B. B. (2000). The relationships among counselors, ESL teachers and students. Professional School Counseling, 3, 339-348.

Cook, A., Pérusse, R. \& Rojas, E. D. (20I2). Increasing academic achievement and college- going rates for Latina/o ELLs:A Survey for school counselor interventions. Journal of Counselor Preparation and Supervision, 4, I4-20.

Council for Accreditation of Counseling and Related Educational Programs (CACREP). (2016). 2016 standards. Retrieved from www.cacrep.org/for-programs/2016-cacrep- standards/

Creswell, J.W. \& Plano Clark, V. L. (2007). Designing and conducting mixed methods research. Thousand Oaks, CA: Sage Publications.

Cummins, J. (2000). Language, power, and pedagogy: Bilingual children in the crossfire (Vol. 23). Clevedon, England: Multilingual Matters.

Dove, M., \& Honigsfeld, A. (20I0). ESL coteaching and collaboration: Opportunities to develop teacher leadership and enhance student learning. TESOL Journal, I (I), 3-22.

Echevarria, J., Short, D., \& Powers, K. (2006). School reform and standards-based education:A model for English-language learners. The Journal of Educational Research, 99 (4), I 95-2 I I.

Fitzgerald, J. (1993). Views on bilingualism in the United States: A selective historical review. Bilingual Research Journal, 17 (I\&2), 35-56.

Freire, P. (1970). Pedagogy of the oppressed. New York: Continuum.

Glaser, B. G., \& Strauss, A. L. (1967). The discovery of grounded theory: Strategies for qualitative research. Piscataway, NJ:Transaction Publishers, Rutgers.

González, N., Moll, L. C., \& Amanti, C. (Eds.). (2005). Funds of knowledge:Theorizing practices in households, communities, and classrooms. Mahwah, NJ: Lawrence Erlbaum Associates.

Hamann, E. T.,Wortham, S., \& Murillo, E. G., Jr. (2002). Education and policy in the New Latino Diaspora. In Wortham, Murillo, \& Hamann (Eds.) Education in the New Latino Diaspora: Policy and the politics of identity. Westport, CT:Ablex Publishing.

Hays, D. G. \& Singh, A.A. (20I2). Qualitative inquiry in clinical and educational settings. New York, NY:The Guilford Press.

Healy, M. (2003). The Scholarship of Teaching: Issues around an Evolving Concept. Journal on Excellence in College Teaching, 14,5-25.

Herrell,A. L. \& Jordan, M. L. (20I5). 50 Strategies for teaching English language learners (5th Edition). Upper Saddle River, NJ: Pearson Education.

Insch, G. S., Moor, J. E., \& Murphy, L. D. (1997). Content analysis in leadership research: Examples, procedures, and suggestions for future use. Leadership Quarterly, 8(I), I-25.
Karathanos, K. (2009). Exploring U S mainstream teachers' perspectives on use of the native language in instruction with English language learner students. International Journal of Bilingual Education and Bilingualism, I2 (6), 6I5-633.

$\mathrm{Kim}, \mathrm{Y} .(2010)$. Scaffolding through questions in upper elementary ELL learning. Literacy Teaching and Learning, I5, I09-136.

Lim, H. (20I5). Social modeling effects on perception of police: Focus on indirect police contact experience among college students. Policing:An International Journal of Police Strategies and Management, 38(4), 675-689.

Matthews, P. (2007). Understanding new ESOL program models for English learners: School counselors as advocates for Latino/a students conference. PowerPoint presentation. CLASE: Center for Latino Achievement and Success in Education, University of Georgia.

Mays, N., \& Pope, C. (2000). Qualitative research in health care: Assessing quality in qualitative research. British Medical Journal, 320, 50-52.

Meyer, L. M. (2000). Barriers to meaningful instruction for English learners. Theory into Practice, 39 (4), 228-236.

Miller, P. H. (2002). Theories of developmental psychology (4 ${ }^{\text {th }}$ ed.). New York, NY:Worth Publishers.

Murillo, E. G., Jr. (2002). How does it feel to be a problem?: "Disciplining" the transnational subject in the American South. In S.Wortham, E. Murillo Jr., and E. Hamann, (Eds.) Education in the New Latino Diaspora, pp. 215-240. Westport, CT:Ablex.

Patton, M. Q. (2002). Qualitative research and evaluation methods ( $3^{\text {rd }}$ ed.). Thousand Oaks, CA: Sage.

Pew Hispanic Research Center. (20I5).Washington, DC. Retrieved from www.pewhispanic.org/states/state/ga/

---. (2017). Washington, DC. Retrieved from: www.pewresearch. org/fact-tank/2017/09/18/how-the-u-s-hispanic-populationis-changing/

Portman, T.A. (2009). Faces of the future: School counselors as cultural mediators. Journal of Counseling \& Development, 87, 2I-27.

Reynolds, S. (2005). Learning is a verb:The psychology of teaching and learning. New York, NY: Holcomb Hathaway.

Salkind, N. J. (2007). Statistics for people who think they hate statistics. Thousand Oaks, CA: Sage Publications, Inc.

Schwallie-Giddis, P., Anstrom, K., Sanchez, P., Sardi,V., \& Granato, L. (2004). Counseling the linguistically and culturally diverse student: Meeting school counselors' professional development needs. Professional School Counseling, 8, I5-23.

Taylor-Powell, E. \& Renner, M. (2003). Analyzing qualitative data In Program development \& evaluation (G3658-12). Retrieved from learningstore.uwex.edu/Assets/pdfs/G3658-I 2.pdf

Tsui, A. B. (2003). Understanding expertise in teaching. Ernst Klett Sprachen. Cambridge, UK: Cambridge University Press.

U.S. Department of Education. (2017). The condition of education 201 7: English language learners in public schools. National Center for Education Statistics. Retrieved from nces. ed.gov/programs/coe/indicator_cgf.asp

Villalba, J.A., Lewis, L. \&Wachter, C. (2007). Examining the academic and personal-social experiences of Latina/o children in southeastern U.S. rural, burgeoning Latino communities. Rural Educator, 28, 12-19.

Villenas, S. (2002) Reinventing Educación in new Latino communities. In S. Wortham, 
E. Murillo Jr., and E. Hamann, (Eds.) Education in the New Latino Diaspora. pp. 17-35. Westport, CT:Ablex.

Vygotsky, L. S. (1978). Mind in society. Cambridge, MA: Harvard University Press.

Vygotsky, L. S. ( I 986). Thought and language. Cambridge, MA: The MIT Press.

Walker, A., Shafer, J., \& liams, M. (2004). "Not in my classroom”: Teacher attitudes towards English language learners in the mainstream classroom. National Association of Bilingual Edu- cation (NABE) Journal of Research and Practice, 2 (I), I30-160. Webster, J., \& Watson, R.T. (2002). Analyzing the past to prepare for the future:Writing a literature review. MIS Quarterly, xiii-xxiii.

World-class Instructional Design and Assessment (WIDA). (20I2). Downloaded from file://C:/Users/User/Downloads/ WIDA booklet_2012\%20Standards\%20Strands_web\%20 (I).pdf

\section{APPENDIX A}

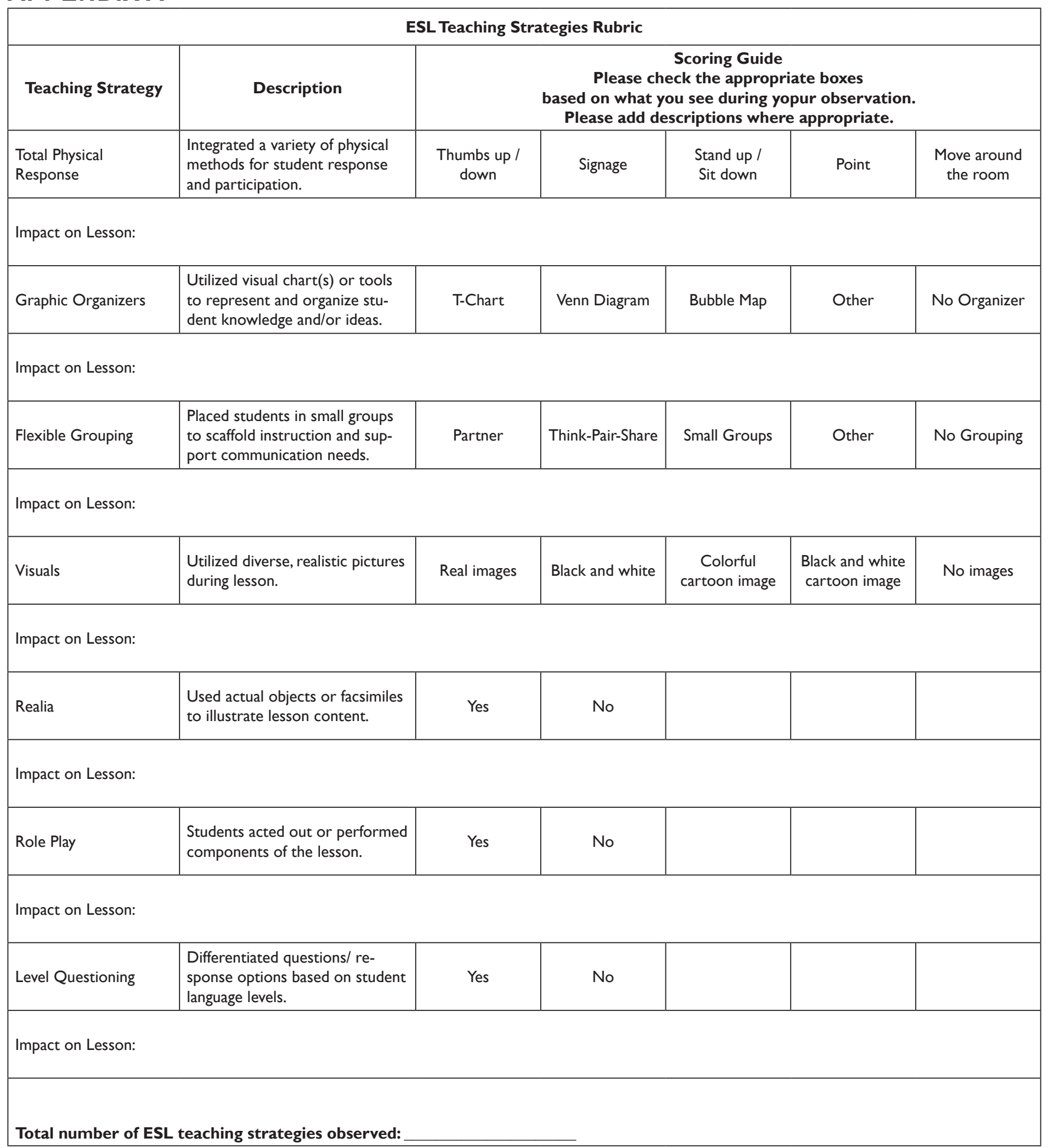




\section{APPENDIX B \\ Presentation Reflection}

I.What is your perception of the intended purpose of the academic/career resource presentations?

2.What should be included in an "engaging" presentation?

3. In what ways did you engage the audience during your academic/career resource presentation?

4.What influenced the strategies you included in your academic/career resource presentation to help make your presentation engaging?

5.What additional strategies could have made the presentation comprehensible for an English Language Learner? 